\title{
UTILIZATION OF JKN DENTAL PROSTHETIC SERVICES AT FIRST LEVEL DENTAL HEALTH FACILITIES IN BALI
}

Gusti Ayu Yohanna Lily*, Widowati Siswomihardjo*, Julita Hendrartini ${ }^{* * \star}$, Haryo Mustiko Dipoyono ${ }^{* \star * *}$, Dewa Made Wedagama ${ }^{* * * *}$

${ }^{*},{ }^{* \star * \star \star}$ Fakultas Kedokteran Gigi Universitas Mahasaraswati Denpasar

**, ***, ${ }^{* * *}$ Fakultas Kedokteran Gigi Universitas Gadjah Mada Yogyakarta

Correspondence: yohanna6969@gmail.com

\section{Keywords:}

JKN, dental prosthesis, predisposing, enabling, need

\begin{abstract}
Background: The utilization of dental prosthesis services in Indonesia is rare, compared to other dental and oral health services. The use of prosthesis services in Bali is still relatively low compared to other parts of Western Indonesia. Based on data from BPJS Kesehatan Denpasar Branch Office, the demand for dental prostheses services by participants in the three working areas of BPJS Kesehatan Denpasar Branch Office is still low.

Method: This research was conducted using quantitative research. The population were all participants providers of FKTP BPJS Kesehatan Badung Regency, and samples were taken through purposive sampling. Quantitative data were analyzed using binary logistic regression.

Result: The results that the predisposing factors for JKN program participants (income, knowledge of dental prostheses, knowledge of JKN dental prosthesis services, perceptions of service quality, and perceptions of cost); enabling factor (access), and the need factor (the perception of pain when losing a tooth) contributions have a significant positive effect on the utilization rate of JKN dental prostheses. The predisposing factors (age and education) and enabling factor (social support) do not have a significant effect on the utilization rate of JKN dental prostheses.

Conclusion: The results that the predisposing factors for JKN program participants contributions have a significant positive effect on the utilization rate of JKN dental prostheses.
\end{abstract}

\section{PENDAHULUAN}

Jaminan kesehatan bagi semua orang merupakan hak azasi manusia. Jaminan kesehatan diselenggarakan secara nasional berdasarkan prinsip asuransi sosial dan prinsip ekuitas. JKN adalah perlindungan kesehatan peserta, yaitu orang yang telah membayar iuran atau yang iurannya dibayarkan oleh pemerintah, memperoleh manfaat pemeliharaan kesehatan dan perlindungan dalam memenuhi kebutuhan dasar kesehatan.

Kehilangan gigi yang menyeluruh berada pada urutan ke-36 dari 291 penyakit yang menyebabkan skor disability adjusted life memburuk ${ }^{1}$. Keadaan tersebut juga mempengaruhi kondisi kesehatan umum. Prevalensi kehilangan gigi yang parah meningkat dengan bertambahnya usia 2. Banyaknya kasus kehilangan gigi di masyarakat, belum diimbangi dengan kesadaran untuk mengganti gigi yang hilang tersebut dengan gigi tiruan ${ }^{3}$. Banyak masyarakat yang telah kehilangan gigi, tetapi sedikit yang ditemukan yang telah menggunakan gigi tiruan ${ }^{4}$.

Pembayaran pelayanan kesehatan kepada Fasilitas Kesehatan Tingkat Pertama (FKTP), dilakukan oleh Badan Penyelenggara Jaminan Sosial (BPJS) Kesehatan atas dasar tarif kapitasi dan nonkapitasi. Tarif nonkapitasi diberikan kepada FKTP yang melakukan pelayanan kesehatan di luar 
lingkup pelayanan kapitasi, meliputi pelayanan protesa gigi yang diberikan berdasarkan rekomendasi dari dokter gigi 5 .

Pemanfaatan layanan protesa gigi di Indonesia belum banyak, dibandingkan layanan kesehatan gigi dan mulut lainnya. Penggunaan layanan protesa di Bali masih tergolong rendah

\section{METODE PENELITIAN}

Penelitian ini dilakukan dengan menggunakan jenis penelitian kuantitatif kuisioner. Metode kuantitatif dilakukan pada peserta BPJS Kesehatan dengan cara pengisian kuesioner penelitian. Penelitian survei dapat mengungkapkan faktor-faktor penentu tingkat utilisasi protesa gigi JKN.

Penelitian ini dilaksanakan di wilayah kerja BPJS Kabupaten Badung Provinsi Bali. Populasi penelitian ini adalah seluruh peserta pada provider FKTP BPJS Kesehatan Kabupaten Badung. Sampel pada penelitian ini sebanyak 403 responden (melebihi sampel minimal 384), diambil secara purposive sampling. dibandingkan dengan daerah Indonesia Bagian Barat lainnya. Berdasarkan data BPJS Kesehatan Kantor Cabang Denpasar, permintaan pelayanan protesa gigi oleh peserta di tiga wilayah kerja BPJS Kesehatan Kantor Cabang Denpasar masih rendah.

Penelitian ini pada dasarnya mencari hubungan antar-variabel, yaitu antara bebas dan varibel terikat. Variabel terikat pada penelitian ini adalah tingkat utilisasi protesa gigi JKN. Adapun variabel bebasnya adalah usia, jenis kelamin, pendidikan, penghasilan, tingkat pengetahuan protesa gigi, tingkat pengetahuan tentang layanan protesa gigi JKN, persepsi kualitas pelayanan, persepsi terhadap iur biaya, akses, dukungan sosial, dan persepsi "sakit" (kehilangan gigi).

\section{HASIL PENELITIAN}

Tabel 1. Hasil Uji Paralel Persamaan Regresi Faktor Predisposing Peserta JKN terhadap Tingkat Utilisasi Protesa Gigi JKN

\begin{tabular}{lcc}
\hline \multicolumn{1}{c}{ Prediktor } & $\begin{array}{c}\text { Koefisien } \\
\text { regresi }\end{array}$ & p-value \\
\hline Konstanta & $-39,427$ & 0,000 \\
Jenis kelamin & $-0,851$ & 0,040 \\
\hline Penghasilan & 1,460 & 0,000 \\
\hline Pengetahuan ttg Protesa Gigi & 2,875 & 0,008 \\
\hline Penget. Pelayanan Protesa Gigi JKN & 2,487 & 0,000 \\
\hline Persepsi Kualitas Pelayanan & 2,778 & 0,000 \\
Persepsi Ttg lur Biaya & 1,957 & 0,000 \\
\hline Keterangan: $\quad$ Jika $p$-value<0,05 berarti koefisien regresi signifikan atau prediktor \\
\hline
\end{tabular}

Tabel 1 menunjukkan persamaan regresi logistik yang memuat 6 variabel bebas (prediktor) yang semuanya telah signifikan (semua $p<0,05$ ). Persamaan logit $(Z)$ yang didapatkan dari langkah terakhir ini adalah:
$Z=-39,427$ (konstanta) - 0,851 (jenis_kelamin) $+1,460$ (penghasilan) $+2,875$ (Pengetahuan_protesa_gigi) $\quad+\quad 2,487$ (Penget_Layanan_protesa_ggi_JKN) $+2,778$ 
(persepsi_kualitas_pelayanan) $\quad+\quad 1,957$ (persepsi_iur_biaya)

Tampak pada Tabel 1 memperlihatkan bahwa ada pengaruh yang signifikan $(p=0,040<0,05)$ jenis kelamin terhadap keputusan peserta JKN memilih menggunakan protesa gigi
JKN dengan nilai koefisien regresi $-0,851$. Nilai negatif pada $-0,851$ menjelaskan bahwa ada pengaruh yang berlawanan antara kenis kelamin dengan keputusan peserta JKN memilih menggunakan protesa gigi JKN. Dengan kata lain perempuan cenderung memilih tidak menggunakan protesa gigi JKN.

Tabel 2. Hasil Uji Paralel Persamaan Regresi Faktor Enabling Peserta JKN terhadap Tingkat Utilisasi Protesa Gigi JKN

\begin{tabular}{|c|c|c|}
\hline Prediktor & $\begin{array}{c}\text { Koefisien } \\
\text { regresi }\end{array}$ & $p$-value \\
\hline Akses & 3,239 & 0,000 \\
\hline Konstanta & $-15,069$ & 0,000 \\
\hline
\end{tabular}

Keterangan: Jika $p$-value $<0,05$ berarti koefisien regresi signifikan atau prediktor berpengaruh bermakna terhadap variabel dependen.

Tabel 2 menunjukkan persamaan regresi logistik yang memuat 1 variabel bebas, yaitu akses, signifikan $(p=0,000<0,05)$ terhadap tingkat utilisasi protesa gigi. Demikian pula dengan konstanta 15,069 juga signifikan $(p=0,000<0,05)$. Persamaan logit (Z) yang didapatkan dari langkah tersebut adalah:

$Z=-15,069$ (konstanta) $+3,239$ (akses)

Nilai koefisien regresi variabel akses adalah 3,239 dengan nilai $p=0,000$. Hasil ini menerangkan bahwa akses berpengaruh signifikan $(p<0,05)$ terhadap keputusan pasien memilih menggunakan protesa gigi JKN. Nilai positif pada 3,239 , artinya ada pengaruh yang positif atau seiring. Jika akses meningkat dalam hal ini semakin baik akses, maka semakin tinggi pula keputusan pasien menggunakan protesa gigi JKN. Dengan kata lain, semakin baik akses menuju lokasi pemeriksaan maka keputusan pasien semakin memilih untuk menggunakan protesa gigi JKN.

Tabel 3. Hasil Uji Paralel Persamaan Regresi Faktor Need Peserta JKN terhadap Tingkat Utilisasi Protesa Gigi JKN

\begin{tabular}{lcc}
\hline \multicolumn{1}{c}{ Prediktor } & $\begin{array}{c}\text { Koefisien } \\
\text { regresi }\end{array}$ & p-value \\
\hline Persepsi Sakit (Kehilangan Gigi) & 1,827 & 0,000 \\
Konstanta & $-9,763$ & 0,000 \\
\hline $\begin{array}{l}\text { Keterangan: Jika p-value }<0,05 \text { berarti koefisien regresi signifikan atau prediktor } \\
\text { berpengaruh bermakna terhadap variabel dependen. }\end{array}$
\end{tabular}

Pada Tabel 3 tertera angka-angka persamaan regresi logistik yang memuat 1 variabel bebas saja yaitu persepsi sakit saat kehilangan gigi signifikan $(p=0,000<0,05)$ terhadap tingkat utilisasi protesa gigi. Demikian pula dengan konstanta 9,763 juga signifikan $(p=0,000<0,05)$. Persamaan logit $(Z)$ yang didapatkan dari langkah tersebut adalah: 
$Z=-9,763($ konstanta $)+1,827$ (persepsi sakit)

Nilai koefisien regresi variabel Persepsi Sakit (Kehilangan Gigi) adalah 1,827 (OR 6,214) dengan nilai $p<0,001$. Hasil ini menerangkan bahwa persepsi sakit saat kehilangan gigi berpengaruh signifikan $(p<0,05)$ terhadap keputusan pasien memilih menggunakan protesa gigi JKN. Nilai positif pada 1,827, artinya ada

\section{DISKUSI}

Hasil penelitian ini mengoreksi temuan Agtini 6 bahwa persentase orang dewasa menggunakan protesa sebanyak 4,5\%. Hasil penelitian ini juga mengoreksi penelitian oleh Giang \& Pfau ${ }^{7}$ bahwa pemanfaatan pelayanan kesehatan oleh lansia lebih besar daripada pemanfaatan pelayanan kesehatan oleh masyarakat di usia produktif. Hasil penelitian ini juga mengoreksi penelitian Kakatkar, dkk $^{8}$ di India, bahwa Kelompok dengan pendidikan yang lebih tinggi cenderung mengunjungi dokter gigi 0,08 kali lebih sering daripada kelompok yang berpendidikan lebih rendah. Ini berarti bahwa semakin tinggi pendidikan, semakin berkurang hambatan seseorang untuk mengunjungi pelayanan kesehatan gigi. Ketidaksesuaian hasil penelitian ini dengan penelitian terdahulu dapat dipahami berdasarkan temuan Shrirao, dkk ${ }^{9}$ bahwa pendidikan dan profesi merupakan faktor yang penting dalam menentukan kemampuan menetapkan pilihan dari seseorang.

Salah satu faktor yang mempengaruhi utilisasi pelayanan kesehatan gigi individu, yaitu akses ke pelayanan kesehatan 10. Aksesibilitas merupakan konsep yang luas berfokus pada memberdayakan seseorang untuk menggunakan pelayanan kesehatan 11. Jika akses meningkat (semakin mudah akses), maka semakin tinggi pula keputusan pasien menggunakan protesa gigi JKN. pengaruh yang positif atau seiring. Jika persepsi sakit saat kehilangan gigi meningkat dalam hal ini semakin baik persepsi pasien saat sakit kehilangan gigi, maka semakin tinggi pula keputusan pasien memilih menggunakan protesa gigi JKN. Dengan kata lain, semakin baik persepsi sakit kehilangan gigi maka keputusan pasien semakin memilih untuk menggunakan protesa gigi JKN.

Semakin baik persepsi pasien saat sakit kehilangan gigi, maka semakin tinggi pula keputusan pasien memilih menggunakan protesa gigi JKN. Hal ini sesuai dengan pendapat Kiyak, dkk 12, bahwa kondisi kesehatan berhubungan dengan utilisasi. Menurut Marino, dkk ${ }^{13}$ persepsi perlunya perawatan gigi dan jumlah gigi yang tersisa merupakan prediktor utilisasi pelayanan kesehatan gigi.

\section{KESIMPULAN}

Hasil penelitian bahwa faktor predisposing peserta program JKN (jenis kelamin, pendapatan, pengetahuan prostesis gigi, pengetahuan pelayanan prostesis gigi JKN, persepsi kualitas pelayanan, dan persepsi biaya); kontribusi faktor enabling (akses), dan faktor need (persepsi nyeri saat kehilangan gigi) berpengaruh positif signifikan terhadap angka utilisasi protesa gigi JKN.

Faktor predisposing (umur dan pendidikan) dan faktor enabling (dukungan sosial) tidak berpengaruh signifikan terhadap angka utilisasi protesa gigi JKN.

\section{UCAPAN TERIMAKASIH}

Dukungan keuangan untuk penelitian ini diberikan oleh hibah dari Universitas Mahasaraswati. Penulis mengucapkan terima kasih kepada rekan-rekan penyelenggara BPJS Tingkat 
Pertama di Kabupaten Badung yang telah menyebarkan kuesioner selama masa pandemi.

\section{DAFTAR PUSTAKA}

1. Marcenes W, Kassebaum NJ, Bernabé E, Flaxman A, Naghavi M, A. Lopez, et al. Global Burden of Oral Conditions in 19902010: A Systematic Analysis. J Dent Res. 2013;92(7):592-7.

2. Kassebaum $\mathrm{NJ}$, Bernabé $E$, Dahiya $M$, Bhandari B, Murray CJL, Marcenes W. Global Burden of Severe Periodontitis in 1990-2010 : A Systematic Review and Metaregression. J Dent Res. 2014;93(11):104553.

3. Murwaningsih S, Nurkhoiriyah $\mathrm{Y}$. Analisis Hubungan Pengetahuan Dan Faktor Perancu Dengan Perilaku Penggunaan Protesa Gigi Di Kota Bandar Lampung. J IIm Keperawatan Sai Betik. 2019;14(2):147.

4. Fonda P, Bennedictus SL, Vonny NW. Gambaran Tingkat Pengetahuan Masyarakat Terhadap Pemakaian Gigi Tiruan. e-Gigi (eG). 2014;2(2).

5. BPJS Kesehatan. Pengelolaan Administrasi Klaim Fasilitas Kesehatan Dalam Penyelenggaraan Jaminan Kesehatan Nasional. Jakarta; 2017.

6. Agtini MD. PERSENTASE PENGGUNA PROTESA DI INDONESIA. Media Penelit dan Pengemb Kesehat. 2012;20(2 Jun):508.
7. Giang TL, Pfau WD. Demographic Changes and the Long-Term Pension Finances in Vietnam: A Stochastic Actuarial Assessment. Popul Ageing. 2009;Vol.1:125-51.

8. Kakatkar G, Article O, Bhat N, Nagarajappa R, Prasad V, Sharda A, et al. Barriers to the Utilization of Dental Services in Udaipur. J Dent Tehran Univ Med Sci. 2011;8:81-9.

9. Shrirao ND, Deshmukh SP, Pande NA, Radke UM. An Evaluation of Patient ' $s$ Decisions Regarding Dental Prosthetic Treatment. 2016;366-71.

10. Heaton LJ, Smith TA, Ph D, Raybould TP. Factors Influencing Use of Dental Services in Rural and Urban Communities: Considerations for Practitioners in Underserved Areas. 2004;(October):10819.

11. Moosazadeh $\mathrm{M}$, Amiresmaili $\mathrm{M}$, Karimi $\mathrm{S}$, Arabpoor M, Afshari M. Apprasial Of Access To Dental Services In South East Of Iran Using Five As Model. 2016;28(May):196200.

12. Kiyak HA, Ph D, Reichmuth M. Barriers to and Enablers of Older Adults ' Use of Dental Services. J Dent Educ. 2005;69(9):975-86.

13. Marino R, Khan A, Tham R, Khew C-W, Stevenson C. Pattern and Factors Associated with Utilization of Dental Services Among Older Adults in Rural Victoria. 2014;Vol.59:504-10. 